\title{
PERBANDINGAN IMBAL HASIL KONTRAK MUDHARABAH DAN PARTISIPASI MODAL DALAM PENGHIMPUNAN DANA BANK SYARIAH DI INDONESIA
}

\author{
Siti Amaroh \\ Dosen Sekolab Tinggi Agama Islam Negeri (STAIN) Kudus \\ amar_stainkudus@yaboo.co.id
}

\begin{abstract}
This study aims to compare the return between mudharabah deposits and equity participating in Indonesia Islamic banking and also to examine the factors that affect the returns. Employee monthly data of 3 Islamic banks over the period 2006-2011 and examined by regression panel model. This research results several substantial findings. First, return on mudharabah deposits is lower than return on equity participating. Second, return on mudrabab deposits is significantly affected by return on assets, profit attributable to third party deposits as percentage of operating profit, and total deposit to total assets. Third, return on equity is also significantly affected by return on assets, profit attributable to equity holders as a percentage of operating profit, and total equity to total assets. Fourth, return on assets affects more bigher return on equity than the return on mudharabah deposits.
\end{abstract}

Keywords: Return, Mudharabah, Equity

\begin{abstract}
Abstrak
Penelitian ini bertujuan untuk membandingkan imbal hasil kontrak mudharabah dan partisipasi modal dalam penghimpunan dana bank syariab di Indonesia dan juga untuk menguji faktor-faktor yang mempengarubinya. Penelitian ini menggunakan data bulanan dari 3 bank syariab selama periode 2006-2001 dan diuji dengan pendekatan regresi panel. Penelitian ini menghasilkan beberapa temuan. Pertama, imbal hasil kontrak mudharabab lebih rendah dibandingkan imbal hasil bagi pemilik modal. Kedua, imbal hasil kontrak mudharabah dipengarubi oleb kemampuan aset bank dalam menghasilkan keuntungan, perbandingan laba yang tersedia bagi pibak ketiga sebagai prosentase laba operasional bank, dan rasio dana pibak ketiga terhadap aktiva bank. Ketiga, imbal hasil bagi pemilik modal dipengarubi juga oleb imbal hasil aset, perbandingan laba yang tersedia bagi pemilik modal dan rasio modal terbadap aktiva bank. Keempat, imbal hasil aset lebih besar pengarubnya terhadap imbal hasil bagi pemilik dibandingkan bagi pibak ketiga.
\end{abstract}

Kata kunci: Imbal Hasil, Mudharabah, Modal 


\section{Pendahuluan}

Islam menawarkan instrumen keuangan yang konsisten dengan keyakinan dan budaya umat Islam, salah satunya adalah bank syariah. Bank syariah menjalankan fungsi utamanya dalam kegiatan penghimpunan dan penyaluran dana berdasarkan prinsip-prinsip syariah yang beroperasi berdasarkan pada dua prinsip utama (Olson \& Zoubi, 2008: 47). Pertama, bank syariah menghindari bunga (interest), baik dalam penerimaan maupun pembayaran pada keseluruhan transaksi. Bunga diyakini sebagai penyebab ketidakadilan distribusi pendapatan dalam masyarakat. Bank syariah merupakan bank bebas bunga dengan tujuan untuk menghindari riba sesuai dengan ketentuan syariat Islam (How, Abdul Karim, \& Verhoven, 2005:75). Penghindaran riba diharapkan menciptakan kesetaraan hubungan antara bank dengan konsumen bank (Rolsy \& Mohd. Zaini, 2008:695). Meskipun tidak beroperasi berdasarkan bunga, bank syariah tetap dapat menjalankan kegiatan operasionalnya dengan menggunakan prinsip profit loss sharing (PLS).

Kedua, prinsip pembagian risiko (risk sharing) dalam bank syariah memiliki arti bahwa bank syariah hanya dapat menjalankan kegiatannya berdasarkan PLS seperti pada bentuk mudharabah dan musyarakah. Bank syariah menerima dana dari investasi masyarakat berbasis mudharabab (profit sharing), dan bank diperbolehkan untuk menggunakan dana tersebut pada kegiatan yang tidak dilarang menurut Islam. Pada sisi yang lain, bank syariah menyalurkan dana kepada mudharib untuk melaksanakan investasi atau kegiatan bisnis yang disetujui oleh bank dengan membagi keuntungan atau kerugian dengan bank berdasarkan rasio yang telah disepakati.

Selain dua prinsip pokok tersebut, bank syariah memberikan batasan-batasan dalam bisnis keuangan Islam (El-Hawary, Grais \& Iqbal, 2007:780). Pertama, risk sharing dalam transaksi keuangan berkaitan symetrical risk-return bagi tiap pihak dalam setiap transaksi; Kedua, materialitas dalam transaksi keuangan harus memiliki hubungan secara langsung maupun tidak langsung dengan transaksi ekonomi riil. Ketiga, tidak ada eksploitasi antar 
berbagai pihak dalam transaksi keuangan, dan keempat, tidak ada pembiayaan pada kegiatan atau proyek yang memproduksi barangbarang yang diharamkan dalam Islam. Tidak hanya harus bebas dari riba, bank syariah juga harus menjalankan transaksi yang bebas dari ketidakpastian (gharar), perjudian (gambling), dan kegiatankegiatan yang tidak halal (Ariss, 2010:102). Dasar-dasar tersebut sebagai bentuk tanggung jawab sosial dan etika bank.

Keunggulan bank syariah salah satunya terdapat pada pengelolaan distribusi laba yang bersifat fleksibel baik bagi pihak ketiga maupun pemilik modal (Farook, Hassan, \& Clinch, 2012:33). Dasar distribusi laba yang digunakan adalah bagi hasil atau bagi pendapatan (revenue sharing) dan juga keuntungan dalam bentuk lain seperti pembayaran biaya sewa, tambahan keuntungan maupun fee untuk akad jasa pelayanan. Meskipun bank syariah juga menghadapi risiko kredit atau risiko likuiditas, walaupun hanya pada tingkatan yang lebih rendah jika dibandingkan risiko suku bunga yang dihadapi bank konvensional, karena kontrak-kontrak pada produk bank syariah berdasarkan pada partisipasi modal, sehingga dapat meminimalisir masalah adverse selection dan moral hazard. Sedangkan pada bank konvensional, return yang diberikan bersifat tetap (fixed return) dalam bentuk bunga (interest) yang mengakibatkan risiko yang dihadapi berupa risiko pasar atau risiko perubahan suku bunga. Sedangkan risiko investasi tidak terjadi karena peminjam telah dijamin melalui agunan sebelum terjadi transaksi peminjaman (pre loan collateral) dan risiko sepenuhnya ditanggung oleh peminjam (debitur). Bank dalam hal ini diposisikan sebagai pemilik pada seluruh jenis kontrak sedangkan peminjam atau investor diposisikan sebagai penanggung risiko yang ditunjukkan melalui pembayaran bunga (interest charges). Bank memiliki kekuasaan untuk menentukan tingkat bunga atau return melalui penilaian biaya modal.

Secara empiris (Diaw dan Mbow, 2011:240) dalam penelitiannya menunjukkan bahwa fenomena perbedaan imbal hasil antara kontrak mudharabah dan partisipasi modal. Imbal hasil kontrak mudharabah (return on mudharabah deposits) dua kali lebih rendah jika dibandingkan dengan imbal hasil partisipasi modal (return on equity) pada penghimpunan dana bank syariah 
pada hasil penelitian tersebut. Menurut risk-return framework, profil risiko yang ditanggung pemilik modal lebih tinggi sehingga imbal hasil yang diharapkan juga lebih tinggi. Sementara dalam konsep bank syariah maka posisi pihak ketiga dalam kontrak mudharabah adalah sebagai investor baik terikat maupun tidak terikat yang seharusnya mendapatkan tingkat keuntungan yang tidak berbeda.

Penelitian pada bank syariah Malaysia juga menunjukkan adanya perbedaan imbal hasil pada jenis investasi kontrak mudharabah dan partisipasi modal (Rosly dan Mohd. Zaini (2008:706). Perbedaan antara return on mudharabah deposits (ROMD) dan return on equity (ROE) memberikan implikasi bahwa bank Islam masih memberikan perlakuan yang sama antara kontrak mudharabah dengan sistem tabungan (fixed deposits) pada bank konvensional di mana risiko bank sepenuhnya berada pada modal bank.

Berdasarkan latar belakang tersebut, penelitian ini bertujuan untuk (1) menguji apakah ada perbedaan imbal hasil antara kontrak mudharabah dan partisipasi modal dalam penghimpunan dana pihak ketiga bank syariah di Indonesia; (2) apa penyebab perbedaan imbal hasil tersebut; dan (3) faktor-faktor apa saja yang menentukan imbal hasil kontrak mudharabah dan partisipasi modal pada bank syariah di Indonesia.

\section{Struktur Modal Bank Syariah}

Teori struktur modal yang dikenal dalam kajian keuangan meliputi beberapa teori seperti trade-off theory, pecking order theory, dan free cash flow theory. Menurut trade-off theory, kinerja sebuah struktur bisnis ditentukan oleh struktur modal optimal yang dicapai berdasarkan pertimbangan cost-benefit atas hutang. Teori pecking order berpendapat sebaliknya dimana struktur modal akan optimal dalam meningkatkan kinerja jika dicapai dengan menggunakan sumber-sumber pendanaan internal. Sedangkan free cash flow theory menyatakan bahwa optimalisasi struktur modal sangat ditentukan oleh tindakan pengelola dalam melakukan pengawasan dan alokasi investasi.

Penerapan struktur modal bank syariah menunjukkan anomali 
dengan beberapa teori tersebut di atas (Archer dan Abdel Karim, 2006:269). Struktur modal bank syariah menggambarkan perpaduan beberapa sumber penghimpunan dana yang menempatkan posisi sumber tersebut pada jenis risiko aset yang sama. Sumber penghimpunan dana bank syariah meliputi kepemilikan saham (shareholders equity), giro (current account), investasi (investment account) dan tabungan (saving account). Sumber dana ini digunakan untuk delapan instrumen keuangan yang berbasis bagi hasil (profit sharing) dan cost-plus pricing. Musyarakah dan mudharabah merupakan instrumen yang berdasarkan prinsip bagi hasil. Sedangkan murabahah, salam, ijarah, ijarab muntabia bittamlik, istishna dan bai bitsaman ajil merupakan instrumen yang berbasis cost-plus pricing (Archer \& Abdel Karim, 2006:270).

Dana yang berasal dari pemegang saham (shareholders'fund) merupakan dana yang dapat ditingkatkan bank melalui penjualan saham umum (common shares) kepada publik. Sesuai dengan ketentuan syariah, bank tidak menerbitkan saham khusus (preferred shares) untuk menghindari pembayaran prosentase dividen dalam jumlah yang tetap terhadap pemegang saham preferen termasuk menentukan cadangan yang diakumulasikan selama beberapa tahun tertentu. Pemegang saham hanya dapat mengendalikan bank melalui dewan komisaris (board of directors).

Giro (current account) merupakan salah satu jenis rekening yang memiliki kesamaan dengan rekening bank konvensional. Nasabah memiliki hak untuk membatalkan dananya berdasarkan permintaan tetapi tidak memiliki hak untuk menerima imbalan (return) terhadap dananya. Sedangkan investasi berpola bagi hasil dihimpun berdasarkan kontrak mudharabah dan tidak dapat disamakan dengan rekening hutang seperti halnya bank konvensional. Dana dalam rekening berpola bagi hasil ini memberikan kepercayaan kepada bank sebagai mudharib dalam bentuk kerjasama usaha (entrepreneurial party) untuk tujuan perdagangan dan investasi. Laba yang diperoleh dibagi antara bank dan nasabah investasi menurut rasio yang disepakati dalam kontrak. Sebagai pemilik bank maka dalam hal ini pemegang saham menerima proporsi laba sebagai insentif terhadap tugasnya dalam mengelola bank terutama untuk produktifitas dana yang berasal 
dari pola investasi.

Adapun pola bagi hasil bank syariah didasarkan pada dua metode yaitu pooling method dan separation method. Berdasarkan pooling method maka seluruh sumber pendanaan harus dibagi berdasarkan keseluruhan pendapatan (revenue) dan biaya (expense) tetapi tidak termasuk yang ditujukan untuk subsidiary atau remunerasi bagi direktur bank maupun fee bagi audit eksternal. Pada separation model maka dipisahkan antara pendapatan dan biaya-biaya operasional investasi dari layanan bank lainnya. Dengan metode ini maka bagi hasil bagi investor hanya didasarkan pada pendapatan dan biaya yang berkaitan dengan investasinya saja.

Model teoritis struktur modal bank Islam atau bank syariah berbasis pada konsep two tier mudharabah (Siddiqi, 2000:30). Mudharabah merupakan konsep yang didukung oleh syariat Islam di mana salah satu pihak menyediakan modal (shabibul maal) sementara pihak yang lain bertindak sebagai wirausaha atau pelaksana usaha (mudharib). Laba berasal dari bisnis yang dimiliki oleh kedua belah pihak berdasarkan rasio keuntungan yang telah disepakati. Kerugian ditanggung oleh shabibul maal jika kerugian bukan disebabkan oleh kelalaian mudharib. Kontrak mudharabah tidak bersifat mengikat karena setiap pihak dapat mengakhiri perjanjian mudharabah tersebut. Mudharib memiliki tanggung jawab penuh dalam menjalankan usahanya dan shabibul maal tidak diperbolehkan melakukan intervensi. Pada sistem two tier mudharabah, bank syariah berperan sebagai mudharib bagi nasabah bank dan pada saat yang sama berperan sebagai shabibul maal bagi para pelaku usaha dalam akses modal usaha. Keuntungan akan dibagi pada ketiga pihak tersebut dengan menurut rasio yang telah disepakati pada saat akad dan kerugian ditanggung sebesar modal yang disertakan.

Kontrak mudharabah dalam bank syariah meliputi investasi tidak terikat (unrestricted investment account) dan investasi terikat (restricted investment account). Perbedaan keduanya terletak pada kemauan pemilik dana dalam memberikan hak dan otoritas terhadap mudharib (Antonio, 2001:138). Pemilik dana pada investasi tidak terikat atau mudharabah mutlaqah memberikan hak dan otoritas 
yang penuh terhadap mudharib, sebaliknya pada investasi terikat atau mudharabah muqayyadah ini pemilik memberikan batasan pada mudharib. Batasan-batasan tersebut meliputi batasan pada jenis investasi, tempat investasi, dan pihak-pihak yang terlibat dalam investasi tersebut.

Pembagian keuntungan dari berbagai jenis kontrak dalam penghimpunan dana bank syariah bergantung pada fluktuasi laba dan kondisi makroekonomi (Anwar, Romansyah, Pramono, \& Watanabe, 2010:298). Menurut Syafe'i Antonio, pembagian keuntungan atau imbal hasil dari masing-masing sumber penghimpunan dana bank syariah ditentukan oleh investment rate, jumlah dana yang tersedia untuk diinvestasikan, dan nisbah imbal hasil (Antonio, 2001:140). Sedangkan rasio profit-sharing ditentukan oleh proporsi aktual laba yang diperoleh dari kegiatan usaha dan bukan pada proporsi modal yang diinvestasikan (Ahmed, 2008:185).

\section{Profil Risiko Bank Syariah}

Menurut perspektif bank syariah, hubungan antara pengelola bank (agent) dan pemilik (principals), digambarkan sebagai hubungan antara manajemen (agent) dan stakebolders (principals). Melalui karakteristik khusus bank syariah, maka struktur tata kelolanya akan melibatkan banyak pihak. Kualifikasi stakeholder dalam perspektif Islam adalah mereka yang hak dan kepemilikannya dipertaruhkan atau terkena risiko (at stake) sebagai akibat dari tindakan bank yang sengaja atau tidak sengaja (Iqbal dan Mirakhor, 2008:386).

Perbankan syariah berdasarkan pada lima prinsip, yaitu prinsip titipan, bagi hasil, jual beli, sewa dan jasa (Antonio, 2001:90134). Masing-masing prinsip diturunkan menjadi berbagai jenis aplikasi dalam kegiatan perbankan syariah yang masing-masing aplikasi memiliki jenis risiko berbeda-beda.

Pertama, prinsip titipan dikenal dengan prinsip wadiah yang berarti titipan murni dari satu pihak kepada pihak lain, baik individu maupun badan hukum yang harus dijaga dan dikembalikan kapan saja si penitip menghendaki. Penerima simpanan berperan sebagai yad al-amanah yang bertanggung jawab atas kehilangan atau kerusakan yang terjadi pada aset yang dititipkan. Sebagai 
konsekuensinya maka semua keuntungan yang dihasilkan dari dana yang dititipkan tersebut menjadi milik bank. Imbalan diberikan kepada bank sebagai akibat risiko yang harus ditanggung, seperti risiko kehilangan maupun kerusakan barang.

Kedua, prinsip bagi hasil dengan akad musyarakah, mudarabah, muzara'ah dan musaqah. Prinsip musyarakah merupakan bentuk akad kerja sama antara dua pihak atau lebih untuk suatu usaha tertentu di mana masing-masing pihak memberikan kontribusi dana dengan kesepakatan bahwa keuntungan dan risiko akan ditanggung bersama sesuai kesepakatan. Musyarakah biasanya diaplikasikan dalam pembiayaan proyek ataupun dalam bentuk modal ventura pada lembaga keuangan khusus yang diperbolehkan melakukan investasi dalam kepemilikan perusahaan. Risiko yang harus ditanggung dapat berupa side streaming atau ketidaksesuaian penggunaan pembiayaan seperti yang disebutkan dalam kontrak, kelalaian atau kesalahan yang disengaja dan penyembunyian keuntungan oleh nasabah terutama nasabah yang tidak jujur. Sedangkan pada akad mudharabah berbentuk kerjasama usaha antara dua pihak dimana pihak pertama (shahibul mal) menyediakan seluruh (100\%) modal, sedangkan pihak lainnya sebagai pengelola. Keuntungan dibagi berdasarkan kesepakatan yang dituangkan dalam kontrak dan bila terjadi kerugian maka ditanggung oleh pemilik modal selama kerugian itu bukan akibat kelalaian pengelola. Risiko yang mungkin terjadi sama dengan risiko pada akad musyarakah.

Ketiga, prinsip jual beli dibagi kedalam tiga jenis akad, yaitu; murabahah, salam dan istishna. Murabahab merupakan jual beli barang pada harga asal dengan tambahan keuntungan yang disepakati. Dalam hal ini penjual harus memberitahukan harga pokok dan menentukan tingkat keuntungan sebagai tambahan. Risiko yang harus ditanggung adalah risiko kelalaian atau risiko pembayaran baik berbentuk kelalaian maupun keterlambatan, risiko fluktuasi harga komparatif, penolakan barang oleh nasabah karena tidak sesuai spesifikasi yang telah disepakati serta risikorisiko yang terjadi selama pengiriman barang. Salam adalah jenis akad dalam prinsip jual beli di mana penyerahan barang dilakukan kemudian hari tetapi pembayaran dilakukan dimuka. Transaksi 
salam mensyaratkan adanya pengukuran dan spesifikasi barang yang jelas dan adanya keridloan yang utuh antara kedua belah pihak. Risiko yang mungkin terjadi adalah risiko pengiriman maupun risiko kerugian akibat spesifikasi barang yang tidak sesuai dengan ekspektasi.

Istishna merupakan kontrak penjualan antara pembeli dan pembuat barang. Dalam kontrak ini pembuat barang menerima pesanan dari pembeli.pembuat barang melalui pihak lain membuat atau membeli barang sesuai spesifikasi yang disepakati dan menjualnya kepada pembeli akhir. Kedua belah pihak bersepakat atas harga serta sistem pembayaran apakah dilakukan dimuka, melalui cicilan atau ditangguhkan sampai suatu waktu di masa yang akan datang. Risiko yang sangat mungkin terjadi adalah risiko pengiriman maupun risiko pembayaran.

Keempat, prinsip sewa (ijarah) yang merupakan pemindahan hak guna atas barang atau jasa melalui pembayaran upah sewa, tanpa diikuti dengan pemindahan kepemilikan atas barang itu sendiri. Manfaat yang diperoleh bank adalah keuntungan sewa dan kembalinya uang pokok. Risiko yang ditanggung seperti risiko nasabah tertundanya pembayaran, dan dan risiko kerusakan barang yang disewa.

Kelima, prinsip jasa meliputi wakalah, kafalah, hawalah, rahn dan qardh. Wakalah adalah pelimpahan kekuasaan oleh seseorang kepada orang lain dalam hal yang diwakilkan. Profil risiko keagenan terjadi antara pemberi amanat dengan penerima amanat.

Kafalah merupakan jaminan yang diberikan oleh penanggung kepada pihak ketiga untuk memenuhi kewajiban pihak kedua atau yang ditanggung. Kafalah juga berarti mengalihkan tanggung jawab seseorang yang dijamin dengan berpegang pada tanggung jawab orang lain sebagai penjamin. Risiko yang dapat terjadi adalah risiko tidak terpenuhinya kewajiban yang ditanggungkan.

Hawalah adalah pengalihan utang dari orang yang berutang kepada orang lain yang wajib menanggungnya. Kontrak hawalah biasanya diterapkan dalam anjak piutang dimana nasabah memiliki piutang kepada pihak ketiga memindahkan piutang tersebut kepada pihak bank atau berbentuk jasa penagihan. Risiko yang dapat terjadi 
dalam kontrak ini adalah kemungkinan terjadinya kecurangan nasabah dalam memberikan data atau terjadinya pengingkaran janji.

Rahn berarti menahan salah satu harta milik peminjam sebagai jaminan atas pinjaman yang diterimanya. Barang yang ditahan tersebut memiliki nilai ekonomis. Dengan demikian, pihak yang menahan memperoleh jaminan untuk dapat mengambil kembali seluruh atau sebagaian piutangnya. Rahn sering disebut sebagai jaminan utang atau gadai. Risiko yang mungkin terjadi adalah tak terbayarnya utang nasabah (wan prestasi) dan risiko penurunan nilai aset yang ditahan.

Sedangkan qardh adalah jenis pemberian harta kepada orang lain yang dapat ditagih atau diminta kembali atau disebut sebagai pinjaman sosial tanpa mengharapkan imbalan. Qardh ini tidak memberikan keuntungan finansial bagi bank karena untuk tujuan sosial. Risiko yang dapat terjadi adalah tidak meningkatnya pendapatan bank dan tidak kembalinya pokok pinjaman yang dapat menurunkan nilai aset bank.

\section{Perkembangan Bank Syariah di Indonesia}

Jika dilihat dari perkembangannya, perbankan Islam sendiri mulai diakui akhir tahun 1940 dan dua dekade kemudian di negaranegara Timur Tengah yang didirikan sebagai bagian dari aspirasi untuk memiliki bank sendiri. Bank Islam mulai berkembang secara luas pada dekade 1960-an di Mesir dengan berdirinya Mit Ghamr Bank sebagai bank rintisan dan selanjutnya pada dekade 1970-an ditandai dengan berdirinya beberapa bank seperti; Nasser Social Bank Cairo (1972), Islamic Development Bank (1975), Dubai Islamic Bank (1975), Kuwait Finance House (1980), Faisal Islamic Bank of Sudan (1977), Dar Al-Maal Al-Islami (1980), dan diikuti oleh bankbank lainnya (Antonio, 2001:19).

Awal 1980-an, transformasi sektor ekonomi dan keuangan pada jalur Islam dilakukan oleh tiga negara yaitu Iran, Pakistan, dan Sudan direspon oleh pasar keuangan Barat, seperti; Citibank, ABN, AMRO, HSBC, dan lainnya dengan membuka sistem keuangan berbasis Islam untuk menghimpun dari negara-negara penghasil minyak dari Timur Tengah dan umat Muslim lainnya pada pasar lokal. 
Bank berbasis Islam sampai sekarang telah beroperasi di sekitar 55 negara dengan 200 institusi, estimasi dana pihak ketiga sekitar \$100 milyar (Shahinpoor, 2009:998). Perkembangan produknya juga semakin meluas meliputi; sukuk, takaful, lindung nilai, manajemen aset, produk derivatif, Islamic Stock Exchange, dan Dow Jones Islamic Index.

Adapun pengembangan sistem perbankan syariah di Indonesia dilakukan dalam kerangka dual-banking system atau sistem perbankan ganda dalam kerangka Arsitektur Perbankan Indonesia (API) untuk menghadirkan alternatif jasa perbankan yang semakin lengkap kepada masyarakat Indonesia. secara bersamasama, sistem perbankan syariah dan perbankan konvensional bersinergi mendukung mobilisasi dana masyarakat secara lebih luas untuk meningkatkan kemampuan pembiayaan bagi sektor-sektor perekonomian nasional. Dengan diberlakukannya Undang-Undang No. 21 Tahun 2008 tentang Perbankan Syariah yang terbit tanggal 16 Juli 2008, maka pengembangan industri perbankan syariah nasional semakin memiliki landasan hukum yang memadai dan akan mendorong pertumbuhan aset tinggi.

Bank syariah terdiri dari Bank Umum Syariah (BUS), Unit Usaha Syariah (UUS), dan Bank Pembiayaan Rakyat Syariah (BPRS). Bank Umum Syariah merupakan jenis bank yang menghimpun dana dari masyarakat dalam bentuk simpanan berupa giro, deposito, tabungan dan atau bentuk lainnya yang dapat disesuaikan dengan itu. Memberi kredit dan menerbitkan surat pengakuan hutang, dikelola awal dengan prinsip-prinsip syariah baik pada awal berdirinya maupun didirikan karena konversi atau melakukan dual banking system (konvensional dan syariah). Keragaman produk BUS, UUS, dan BPRS berdasarkan pada prinsip-prinsip syariah.

Bank Indonesia merumuskan Grand Strategy pengembangan pasar perbankan syariah di Indonesia sebagai strategi komperehensif pengembangan pasar yang meliputi aspek-aspek strategis yaitu penetapan visi 2010 sebagai industri perbankan terkemuka di ASEAN, pembentukan citra baru perbankan syariah nasional yang bersifat inklusif dan universal, pemetaan pasar secara lebih akurat, pengembangan produk yang lebih beragam, peningkatan layanan, 
serta strategi komunikasi baru yang memposisikan perbankan syariah. Strategi tersebut diimplementasikan dengan programprogram sebagai berikut:

Pertama, menerapkan visi baru pengembangan perbankan syariah pada fase I tahun 2008 dengan membangun pemahaman perbankan syariah sebagai Beyond Banking dengan pencapaian target asset sebesar Rp 50 triliun dan pertumbuhan industri sebesar 40\%, fase II tahun 2009 menjadikan perbankan syariah sebagai perbankan syariah paling atraktif di ASEAN dengan pencapaian target asset Rp 87 triliun sebesar 75\%. Fase III tahun 2010 menjadikan perbankan syariah Indonesia sebagai perbankan syariah terkemuka di ASEAN dengan pencapaian target asset sebesar Rp 124 triliun dan pertumbuhan industri sebesar 81\%

Kedua, program pencitraan baru perbankan syariah yang meliputi aspek positioning, differentiation, dan branding. Positioning baru bank syariah sebagai perbankan yang saling menguntungkan kedua belah pihak, aspek diferensiasi dengan keunggulan kompetitif dengan produk dan skema beragam, transparan, kompeten dalam keuangan dan beretika, teknologi informasi yang selalu up-date dan user friendly, serta adanya ahli investasi syariah yang memadai.

Ketiga, program pemetaan baru secara akurat terhadap potensi pasar perbankan syariah. Layanan diarahkan pada pelayanan jasa bank syariah sebagai layanan universal bagi semua lapisan masyarakat sesuai dengan strategi masing-masing bank syariah. Program lainnya diarahkan pada pengembangan produk, program peningkatan kualitas layanan yang didukung oleh Sumber Daya Manusia (SDM) yang kompeten dan penyediaan teknologi informasi, dan program sosialisasi dan edukasi masyarakat secara lebih luas dan efisien melalui berbagai sarana komunikasi langsung maupun tidak langsung (media cetak, elektronik, online/website) yang bertujuan untuk memberikan pemahaman tentang kemanfaatan produk serta jasa perbankan syariah.

Secara historis, Bank Muamalat Indonesia adalah bank yang pertama kali lahir di Indonesia dengan prinsip syariah dan selanjutnya disusul dengan berdirinya bank syariah lain, seperti; 
Bank Syariah Mandiri, Bank Mega Syariah Indonesia, dan bank syariah lainnya. Tabel 1 menunjukkan perkembangan bank berbasis syariah di Indonesia antara 2006-2011 berdasarkan jumlah dan jenis bank. Sampai saat ini telah terdapat 11 BUS, 24 UUS, dan 155 BPRS. Beberapa bank merupakan hasil spin off atau pemisahan dari bank induk Unit Usaha Syariah (UUS) menjadi Bank Umum Syariah (BUS).

Tabel 1

Pertumbuhan Jumlah Bank Syariah di Indonesia

\begin{tabular}{lcccccc}
\hline \multicolumn{1}{c}{ Jenis Bank } & \multicolumn{7}{c}{ Jumlah Bank } \\
& 2006 & 2007 & 2008 & 2009 & 2010 & 2011 \\
\hline Bank Umum Syariah & 3 & 3 & 3 & 6 & 11 & 11 \\
Unit Usaha Syariah & 19 & 21 & 28 & 25 & 23 & 24 \\
BPR Syariah & 105 & 114 & 131 & 138 & 150 & 155 \\
\hline
\end{tabular}

Sumber: Statistik Perbankan Indonesia, November 2012

Penghimpunan dana bank syariah dalam praktiknya berbentuk giro, deposito, pinjaman pihak kedua, investasi masyarakat, modal disetor maupun sumber-sumber lainnya yang sesuai dengan ketentuan syariah. Salah satu sumber pendanaan yang diprioritaskan adalah dana yang bersumber dari pihak ketiga dalam bentuk giro wadiah, deposito mudharabah, dan tabungan mudharabah. Tabel 2 menunjukkan kinerja bank syariah dari sisi aset, penghimpunan dana pihak ketiga, dan pembiayaan. Aset bank syariah meliputi kas dan setara kas, surat berharga, pembiayaan, dan aktiva tetap bank. Peningkatan aset terjadi baik pada Bank Umum Syariah, Unit Usaha Syariah, maupun Bank Pembiayaan Rakyat Syariah selama periode 2006-2011. Demikian pula terjadi peningkatan pada penghimpunan dana pihak ketiga dan penyaluran dana bank dalam bentuk pembiayaan. 
Tabel 2

Kinerja Bank Syariah di Indonesia

(Milyar Rupiah)

\begin{tabular}{|c|c|c|c|c|c|c|}
\hline Jenis Bank & 2006 & 2007 & 2008 & 2009 & 2010 & 2011 \\
\hline \multicolumn{7}{|l|}{ Bank Umum Syariah } \\
\hline$>$ Aset & 21.151 & 27.286 & 34.036 & 48.014 & 79.186 & 116.930 \\
\hline$>$ Dana Pihak Ketiga & 17.216 & 21.966 & 27.734 & 39.624 & 64.335 & 96.548 \\
\hline$>$ Pembiayaan & 16.113 & 20.717 & 26.109 & 34.452 & 56.357 & 83.704 \\
\hline \multicolumn{7}{|l|}{ Unit Usaha Syariah } \\
\hline$>$ Aset & 5.571 & 9.252 & 15.519 & 18.076 & 18.333 & 28.536 \\
\hline$>$ Dana Pihak Ketiga & 3.456 & 6.045 & 9.118 & 12.648 & 11.702 & 18.867 \\
\hline$>$ Pembiayaan & 4.332 & 7.227 & 12.090 & 12.435 & 11.824 & 18.952 \\
\hline \multicolumn{7}{|l|}{ BPR Syariah* } \\
\hline$>$ Aset & - & 1.203 & 1.693 & 2.126 & 2.736 & 3.520 \\
\hline$>$ Dana Pihak Ketiga & - & 708 & 570 & 1.251 & 1.604 & 2.095 \\
\hline$>$ Pembiayaan & - & 877 & 1.257 & 1.587 & 2.060 & 2.676 \\
\hline
\end{tabular}

Sementara pada Tabel 3 menunjukkan tingkat imbal hasil deposito dari tahun 2006-2011. Imbal hasil deposito syariah berkisar antara 6\%-8\% untuk deposito 1 bulan, sedangkan tingkat imbal hasil yang memiliki rata-rata paling tinggi untuk deposito syariah >12 bulan dengan tingkat imbal hasil tertinggi 48,14\% pada periode 2011. Meningkatnya pertumbuhan dana pihak ketiga akan berimplikasi pada meningkatnya distribusi bagi hasil kepada nasabah. Karena deposito memperlihatkan pertumbuhan yang lebih cepat dibanding pertumbuhan giro dan tabungan mengakibatkan beban peningkatan bagi hasil yang harus dibayarkan menjadi lebih tinggi terutama bagi nasabah deposito.

Penyaluran dana bank syariah terutama untuk jenis-jenis pembiayaan yang beragam dan pembiayaan merupakan salah satu keunggulan bank syariah. Tugas bank syariah adalah menghimpun dana untuk kemudian menyalurkan dalam bentuk pembiayaan. Bentuk-bentuk akad pembiayaan bank syariah meliputi mudharabah, musyarakah, murabahah, salam, istishna, ijarah, qardh dan multijasa lainnya. 
Tabel 3

Ekuivalens Imbal Hasil/Fee/Bonus

Bank Umum Syariah dan Unit Usaha Syariah 2006-2012

\begin{tabular}{lcccccc}
\hline \multicolumn{1}{c}{ Keterangan } & 2006 & 2007 & 2008 & 2009 & 2010 & 2011 \\
\hline $\begin{array}{l}\text { Dana Pihak Ketiga } \\
\text { 1. Giro iB }\end{array}$ & $1,27 \%$ & $1,07 \%$ & $1,18 \%$ & $0,96 \%$ & $1,20 \%$ & $2,04 \%$ \\
2. Tabungan iB & $3,72 \%$ & $3,32 \%$ & $3,61 \%$ & $2,76 \%$ & $3,06 \%$ & $3,21 \%$ \\
3. Deposito iB & & & & & & \\
a. 1 Bulan & $8,96 \%$ & $7,63 \%$ & $8,22 \%$ & $6,92 \%$ & $6,90 \%$ & $7,14 \%$ \\
b. 3 Bulan & $9,81 \%$ & $7,93 \%$ & $9,10 \%$ & $6,68 \%$ & $6,68 \%$ & $7,71 \%$ \\
c. 6 Bulan & $9,57 \%$ & $8,25 \%$ & $8,67 \%$ & $7,15 \%$ & $7,15 \%$ & $8,95 \%$ \\
d. 12 Bulan & $9,99 \%$ & $8,34 \%$ & $8,34 \%$ & $7,32 \%$ & $7,32 \%$ & $6,30 \%$ \\
e. > 12 Bulan & $10,04 \%$ & $7,17 \%$ & $8,63 \%$ & $9,65 \%$ & $9,65 \%$ & $48,14 \%$ \\
Pembiayaan & & & & & & \\
1. Akad Mudharabah & $13,73 \%$ & $16,93 \%$ & $19,38 \%$ & $19,11 \%$ & $17,39 \%$ & $16,05 \%$ \\
2. Akad Musyarakah & $10,25 \%$ & $11,23 \%$ & $11,37 \%$ & $11,77 \%$ & $14,52 \%$ & $13,64 \%$ \\
3. Akad Murabahah & $12,09 \%$ & $14,66 \%$ & $14,92 \%$ & $16,07 \%$ & $15,30 \%$ & $14,72 \%$ \\
4. Akad Salam & - & - & - & - & - & - \\
5. Akad Istishna & $13,46 \%$ & $14,30 \%$ & $14,99 \%$ & $13,89 \%$ & $13,37 \%$ & $14,24 \%$ \\
6. Akad Ijarah & $0,66 \%$ & $0,16 \%$ & $0,88 \%$ & $0,76 \%$ & $0,46 \%$ & $0,16 \%$ \\
7. Akad Qardh & $5,33 \%$ & $2,89 \%$ & $3,42 \%$ & $4,34 \%$ & $3,89 \%$ & $4,31 \%$ \\
\hline
\end{tabular}

Sumber: Statistik Perbankan Syariah, November 2012

\section{Metode Penelitian}

Penelitian ini mengembangkan model Rosly dan Zaini (2008:702) dan Diaw dan Mbow (2011:236) yang menguji kesenjangan abnormal pada imbal hasil kontrak mudharabah atau Return on Mudharabah Deposits (ROMD) dengan imbal hasil partisipasi modal oleh pemilik bank atau Return on Equity (ROE). Sampel penelitian ini adalah bank syariah meliputi Bank Muamalat Indonesia, Bank Syariah Mandiri, dan Bank Syariah Mega Indonesia antara 20062011. Jenis data pooled data yaitu gabungan antara cross section dan time series yang bersumber dari laporan keuangan bulanan bank syariah yang diakses dari database Bank Indonesia.

Tahap pertama dalam pengujian ini dengan melakukan regresi pada faktor-faktor yang mempengaruhi imbal hasil dana pihak ketiga pada kontrak mudharabah. Faktor-faktor yang 
mempengaruhi imbal hasil kontrak mudharabab atau Return on Mudharabab Deposits (ROMD) antara lain Return on Assets (ROA), laba yang tersedia untuk pihak ketiga dibagi laba operasional (PADOP), dan Total Deposits to Total Assets (TDTA). Tahap kedua melakukan regresi terhadap faktor-faktor yang mempengaruhi imbal hasil partisipasi modal. Faktor-faktor yang mempengaruhi imbal hasil bagi pemilik modal atau Return on Equity (ROE) meliputi Return on Assets (ROA), laba yang tersedia bagi pemilik modal dibagi laba operasional (PAEOP) dan Total Equity to Total Assets (TETA).

Adapun model statistik dari kedua pengujian regresi tersebut adalah sebagai berikut:

$$
\begin{aligned}
& \operatorname{ROMD}_{t}=\beta_{1}+\beta_{2} \text { ROA }_{t}+\beta_{3} \text { PADOP }_{t}+\beta_{4} \text { TDTA }_{t}+\varepsilon_{t} \ldots \ldots \ldots \ldots \ldots \ldots \\
& \operatorname{ROE}_{t}=\beta_{1}+\beta_{2} \text { ROA }_{t}+\beta_{3} \text { PAEOP }_{t}+\beta_{4} \text { TETA }_{t}+\varepsilon_{t} \ldots \ldots \ldots \ldots \ldots \ldots \ldots \ldots \ldots \ldots \ldots
\end{aligned}
$$

Definisi operasional dari masing-masing variable tersebut diatas adalah sebagai berikut:

Keterangan:

(1) ROMD = Return on Mudharabah Deposits, yaitu laba yang tersedia bagi pihak ketiga dibagi dengan total dana pihak ketiga

(2) $\mathrm{ROE}=$ Return on Equity, yaitu laba yang tersedia bagi pemilik modal dibagi dengan jumlah partisipasi modal

(3) $\mathrm{ROA}=$ Return on Assets, yaitu laba operasi dibagi dengan total aktiva bank

(4) $\mathrm{PADOP}=$ Profit Attributable to Deposits as Percentage of Operating Profit, yaitu laba yang tersedia bagi pihak ketiga sebagai prosentase dari laba operasional bank

(5) $\mathrm{PAEOP}=$ Profit Attributable to Equity as Percentage of Operating Profit, yaitu laba yang tersedia bagi pemilik modal sebagai prosentase dari laba operasional bank

(6) TDTA = Total Deposit to Total Assets, yaitu jumlah dana pihak ketiga dibagi jumlah aktiva bank

(7) TETA = Total Equity to Total Assets, yaitu jumlah modal bank dibagai jumlah aktiva bank 


\section{Analisis}

Penelitian ini menggunakan data bulanan tiga bank syariah di Indonesia antara 2006-2011 dengan jumlah sampel sebanyak 216. Tabel 4 memberikan gambaran tentang nilai rata-rata (MEAN), standard deviasi (SD), nilai terendah (MIN), dan nilai tertinggi (MAX) dari masing-masing variabel. Rata-rata imbal hasil dana pihak ketiga (ROMD) sebesar 1,31\%, standard deviasi 1,08\%, nilai terendah $-0,70 \%$ dan nilai tertinggi $6,99 \%$. Rata-rata imbal hasil untuk pemilik modal (ROE) sebesar 11,84\%, standard deviasi 10,68\%, nilai terendah $-5,86 \%$ dan nilai tertinggi 110,03\%. Rata-rata kemampuan bank untuk menghasilkan laba berdasarkan nilai aktiva (ROA) sebesar 1,11\%, standard deviasi 0,93\%, nilai terendah -0,62 dan nilai tertinggi 6,15\%. Rata-rata perbandingan imbal hasil kepada pihak ketiga dengan laba operasional bank (PADOP) sebesar 398,47\%, standard deviasi $1078,47 \%$, nilai terendah $-766,12 \%$ dan nilai tertinggi 10830,05\%. Rata-rata perbandingan imbal hasil bagi pemilik modal dengan laba opersional bank (PAEOP) sebesar 93,87\%, standard deviasi $66,62 \%$, nilai terendah $18,14 \%$ dan nilai tertinggi $941,88 \%$. Rata-rata rasio dana pihak ketiga (TDTA) sebesar 85,01\%, standard deviasi 3,67\%, nilai terendah $74,13 \%$ dan nilai tertinggi $93,18 \%$. Sedangkan rata-rata rasio modal (TETA) sebesar 8,66\%, standard deviasi 6,52, nilai terendah 5,59\% dan nilai tertinggi 13,47\%.

Berdasarkan data tersebut menunjukkan bahwa perbandingan rata-rata imbal hasil kontrak mudharabah (ROMD) sebesar 1,31\% lebih rendah dari imbal hasil bagi pemilik modal (ROE) sebsesar $11,84 \%$. Sementara itu rata-rata dana pihak ketiga sebesar 85,01\% lebih tinggi dibandingkan rata-rata partisipasi modal bank yang hanya sebesar 8,66\%. Namun demikian jika dilihat dari standard deviasi sebagai pengukur besarnya risiko maka risiko yang ditanggung oleh pemilik sebesar 10,68\% lebih tinggi dibandingkan risiko yang ditanggung oleh pihak ketiga sebesar 1,08\%. Hasil ini secara teoritis konsisten dengan risk-return framework dimana pihak yang menanggung risiko (risk) yang lebih tinggi akan meminta imbal hasil (return) yang lebih tinggi pula. Akan tetapi secara praksis, hasil ini mengkonfirmasi beberapa penelitian terdahulu yang menjelaskan bahwa masih ada kesenjangan yang cukup tinggi pada 
pola pembagian keuntungan atau imbal hasil antara pihak ketiga dan pemilik modal. Bank syariah masih memperlakukan kontrak mudharabah seperti halnya tabungan pada bank konvensional dimana imbal hasil bagi pihak ketiga atau nasabah selalu rendah dan konstan (Diaw dan Mbow, 2011: 238).

Rosly dan Mohd. Zaini (2008: 705) memberikan alasan mengapa ROMD lebih rendah dibandingkan ROE. Pertama, modal pada bank syariah menyerap seluruh risiko baik risiko sistematis maupun non sistematis. Meskipun dalam teori, kontrak mudharabah dapat terpengaruh oleh risiko pasar namun risiko ini dalam kegiatan operasional tidak diakui oleh pengambil kebijakan bank syariah. Kedua, investasi oleh bank dalam bentuk murabahah dan instrumen penyaluran dana sejenis menghasilkan laba (margin) yang kecil. Untuk menjaga agar pendapatan dan laba tetap tinggi maka bank harus meningkatkan volume transaksi dalam jumlah yang besar.

Tabel 4

\section{Statistik Deskriptif}

\begin{tabular}{lcccc}
\hline & MEAN & SD & MIN & MAX \\
\hline ROMD (\%) & 1,31 & 1,08 & $-0,70$ & 6,99 \\
ROE (\%) & 11,84 & 10,68 & $-5,86$ & 110,03 \\
ROA (\%) & 1,11 & 0,93 & $-0,62$ & 6,15 \\
PADOP (\%) & 398,47 & 1078,47 & $-766,12$ & 10830,05 \\
PAEOP (\%) & 93,87 & 66,62 & 18,14 & 941,88 \\
TDTA (\%) & 85,01 & 3,67 & 74,13 & 93,18 \\
TETA (\%) & 8,66 & 6,52 & 5,59 & 13,47 \\
\hline
\end{tabular}

Sumber: Hasil olah data dengan SPSS 16

Gambar 1 menunjukkan fluktuasi PADOP tertinggi pada periode 2007 dan mengalami penurunan dalam jangka waktu yang panjang dan kemudian mengalami peningkatan yang cukup tinggi pada periode 2010. Penurunan PADOP menunjukkan lemahnya pihak ketiga dalam mempengaruhi pengelola bank dalam penentuan imbal hasil. Pihak ketiga hanya dapat mempengaruhi bank dalam hal ini melalui disiplin pasar. Tindakan disiplin pasar merupakan pengawasan oleh konsumen bank yang dapat dilakukan melalui beberapa cara seperti meminta imbal hasil yang lebih tinggi dan jika tidak dipenuhi maka nasabah bank akan menarik dananya dari 
bank yang bersangkutan (Hamalainen, 2006:101). Selain itu nasabah bank juga dapat mendorong bank untuk mengurangi profil risiko dan melakukan efisiensi agar bank dapat meningkatkan pembagian keuntungan yang lebih tinggi tidak hanya bagi pemilik bank tetapi juga pada pihak ketiga atau masyarakat sebagai konsumen bank.

Adapun manfaat sosial disiplin pasar ini meliputi:

Pertama, sebagai bentuk tindakan koreksi bagi bank dalam pengambilan risiko. Jika disiplin pasar meningkat maka itu berarti dapat mengurangi moral hazard bank seperti pada bentuk perubahan rasio distribusi bagi hasil oleh bank tanpa rasionalisasi yang jelas dan ketidakmampuan bank untuk menerapkan sistem profit-loss sharing sebagai dasar operasional bank syariah (Warde, 2009:332). Disiplin pasar dalam hal ini akan menjadi efektif jika penetapan marjin penyaluran dana dan alokasi dana portofolio menggambarkan preferensi masyarakat terhadap risiko.

Kedua, disiplin pasar dapat mendorong bank untuk meningkatkan efisiensi melalui perubahan manajemen atau tidak lagi ikut dalam kegiatan industri perbankan. Biaya sosial pengawasan bank dapat diturunkan jika para pengambil kebijakan memberikan penekanan yang lebih besar pada kekuatan pasar dan dapat memberi informasi bank-bank yang baik diantara yang buruk (good from bad). Manfaat ini berasal dari kenyataan bahwa pasar bersifat luas, anonim, mencakup berbagai kelompok entitas, dan pengawas bank yang konstan terhadap kegiatan bank. Pasar dapat bereaksi dengan lebih cepat dibandingkan pengambil kebijakan dalam merespon peningkatan risiko sehingga dapat mengurangi risiko sistemik (Hamalainen, 2006:102). 


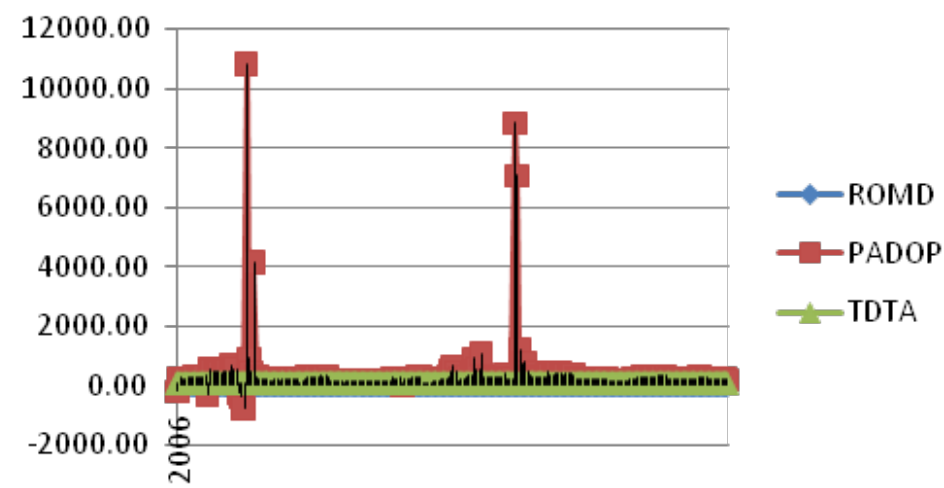

Gambar 1

\section{Resio-rasio Pihak Ketiga}

Gambar 2 menjelaskan fluktuasi PAEOP tertinggi terjadi pada periode sebelum 2007 dan selanjutnya mengalami penurunan dan meningkat cukup tinggi pada periode 2009. Berbeda dengan pola PADOP, pola PAEOP cenderung meningkat dan menunjukkan peran pemilik modal lebih tinggi terutama dalam voting rights. Hak pemilik dilakukan dengan beberapa cara seperti mempengaruhi pasar primer modal bank, mempengaruhi perilaku pengelola bank melalui beberapa kebijakan penentuan modal atau penarikan saham bilamana bank pengelola tidak mampu melakukan efiensi dan meningkatkan keuntungan (De Ceuster dan Masschelein, 2003:275)

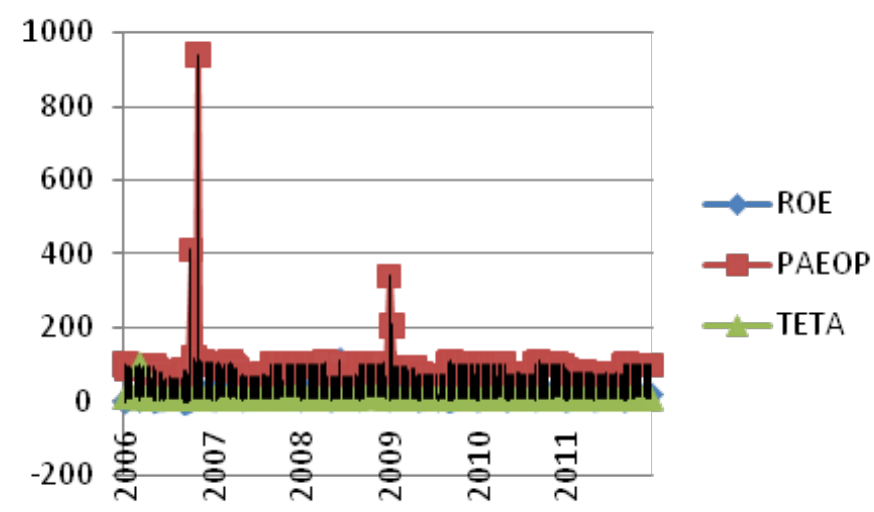

Gambar2

\section{Resio-rasio Pemilik Modal}


Nilai koefisien determinasi $\left(\mathrm{R}^{2}\right)$ dari pengujian regresi persamaan (1) yang disajikan pada persamaan (3) sebesar 99,9\% yang menunjukkan besarnya sumbangan ROA, PADOP, dan TDTA mendekati nilai absolut 100\%. Jika ROA dan PADOP memiliki arah hubungan positif, sebaliknya TDTA memiliki arah negatif yang berarti bahwa peningkatan rasio dana pihak ketiga menurunkan imbal hasil bagi pihak ketiga. ROMD dipengaruhi ROA sebesar 1,166, PADOP sebesar 0,0000078, dan TDTA sebesar-0,016. ROA memberikan kontribusi tertinggi terhadap peningkatan ROMD.

$$
\begin{aligned}
& R O M D=1,341+1,166 R O A+0,0000078 P A D O P-0,016 T D T A \\
& \begin{array}{lllll}
\text { (se) } & (0,058) & (0,003) & (0,000) & (0,001)
\end{array} \\
& \begin{array}{llll}
(p \text {-value }) & (0,000) & (0,000) & (0,001)
\end{array} \\
& R^{2}=99,9 \%
\end{aligned}
$$

Sedangkan nilai koefisien determinasi $\left(\mathrm{R}^{2}\right)$ dari persamaan regresi (2) disajikan pada persamaan (4) menunjukkan sebesar $86,7 \%$ sebagai kontribusi ROA, PAEOP, dan TETA terhadap ROE. Seluruh variable signifikan pada $\alpha=1 \%$. Seluruh variabel bertanda positif kecuali TETA sehingga kenaikan variabel ini secara statistik menurunkan ROE. Hasil ini menunjukkan bahwa ROE dipengaruhi oleh ROA sebesar 11,004, PAEOP sebesar 0,017, dan TETA sebesar $-1,102$ dan ROA memberikan kontribusi tertinggi dalam peningkatan ROE.

$$
\begin{aligned}
& \mathrm{ROE}=7,113+11,004 \mathrm{ROA}+0,017 \mathrm{PAEOP}-1,102 \mathrm{TETA} \\
& \begin{array}{lllll}
(\mathrm{se}) \quad(1,410) \quad(0,296) & (0,004) \quad(0,171)
\end{array} \\
& \begin{array}{llll}
\text { (p-value) } & (0,000) \quad(0,000) \quad(0,001) \quad(0,000)
\end{array} \\
& \mathrm{R} 2=86,7 \%
\end{aligned}
$$

Dari kedua hasil uji regresi memberikan sebuah temuan empiris bahwa pengaruh ROA lebih tinggi pada ROE dibandingkan pada ROMD. Hasil ini memberikan implikasi bahwa peningkatan keuntungan akan meningkatkan imbal hasil bagi pemilik lebih tinggi dibandingkan bagi pihak ketiga dengan perbandingan jumlah dana pihak ketiga rata-rata $85,01 \%$ sedangkan dana pemilik rata-rata $8,66 \%$. 


\section{Kesimpulan}

Model penghimpunan dana bank syariah meliputi dana yang bersumber dari pihak ketiga dalam bentuk investasi dan non investasi dan dana bersumber dari pemilik modal. Sumber dana investasi pihak ketiga meliputi dana dengan kontrak mudharabah baik mudharabah muqayyadah maupun mudharabah mutlaqah. Berdasarkan pola tersebut, bank syariah menerapkan sistem pembagian hasil keuntungan sesuai dengan proporsi dana yang diinvestasikan dan tingkat keuntungan yang dihasilkan oleh bank. Karakteristik ini membedakannya dengan bank konvensional dimana nasabah memiliki klaim tetap terhadap aset bank yang ditentukan diawal melalui penentuan tingkat bunga (interest rate). Ketidakpastian pendapatan dan juga perubahan nilai aset bank ditanggung oleh pemegang saham. Sedangkan pada bank syariah risiko ditanggung bersama karena prinsip bagi hasil memiliki konsekuensi pada pembagian risiko (risk sharing).

Berdasarkan hasil pengujian statistik, penelitian ini menghasilkan beberapa hal. Pertama, imbal hasil pihak ketiga dalam kontrak mudharabah (ROMD) lebih rendah dibandingkan dengan imbal hasil bagi pemilik modal (ROE) dengan partisipasi investasi yang lebih tinggi dibandingkan dengan partisipasi modal pemilik. Kedua, ROMD dipengaruhi secara signifikan oleh ROA, PADOP, dan TDTA. Dan ketiga, ROE juga dipengaruhi secara signifikan oleh ROA, PAEOP, dan TETA. Namun demikian peningkatan rasio dana pihak ketiga (TDTA) dan rasio modal (TETA) berpengaruh negatif terhadap imbal hasil baik bagi pihak ketiga maupun pemilik. Dan keempat, kontribusi dana pihak ketiga yang lebih tinggi dibandingkan dana pemilik belum mampu meningkatkan kemakmuran pihak ketiga karena jumlah imbal hasil yang lebih kecil.

\section{Daftar Pustaka}

Ahmed, Gaffar A. 2008. "The Implication of Using Profit and Loss Sharing Modes of Finance in the Banking System, with a Particular Reference to Equity Participation Method in Sudan", Humanomics, Vol. 24, No. 3, 182-206 
Anwar, S., D. Romansyah, S. Pramono, dan K. Watanabe. 2010. "Treating Return of Mudharabah Time Deposits as investment Instrument: A Utilization of Artificial Neural Networks (ANNs)", Humanomics, Vol. 26, No. 4, 296-309

Archer, S. \& Rifaat A. Abdel Karim. 2006. "On Capital Structure, Risk Sharing and Capital Adequacy in Islamic Banks", International Journal of Theoretical and Applied Finance, Vol. 9, No. 3, 269-280

Ariss, Rima T. 2010. "Competitive Conditions in Islamic and Conventional Banking: A Global Perspective", Review of Financial Economics 19, 101-108

De Ceuster, Marc. J. K. dan Nancy Masschelein. 2003, "Regulating Banks Through Market Discipline; A Survey of The Issues", Journal of Economics Surveys Vol. 17, No. 5, 749-766

Diaw, Abdou dan Abdoulaye Mbow. 2011. "A Comparative Study of the Returns on Mudharabah Deposit and on Equity in Islamic Banks", Humanomics, vol. 27, No. 4, 229-242

El-Hawary, D., W. Grais, dan Z. Iqbal. 2007. "Diversity in the Regulation of Islamic Financial Institutions", The Quarterly Review of Econommics and Finance 46, 778-800

Farook, S., M. K. Hassan. dan G. Clinch. 2012, "Profit Distribution Management by Islamic Banks: An Empirical Investigation", The Quarterly of Economics and Finance 5, 333-347

Hamalainen, Paul. 2006. "Market Discipline and Regulatory Authority Oversight of Banks: Complement Not Substitutes", The Service Industries Journal, Vol. 26, No. 1, 97-117

How, Janice, C. Y., Melina, Abdul Karim, \& Peter Verhoven. 2005. "Islamic Financing and Bank Risks: The Case of Malaysia", Thunderbird International Business Review, Vol. 47(I), 75-94

Iqbal, A. dan A. Mirakhor. 2008. Pengantar Keuangan Islam: Teori dan Praktik, Penerjemah: A. K. Anwar, Jakarta: Kencana

Olson, Z. dan Taisier A. Zoubie. 2008. "Using Accounting Ratios to Distinguish between Islamic and Conventional Banks in the GCC Region", The International Journal of Accounting 43, 45-65

Rosly, Saiful A. \& Mohammad A. Mohd Zaini. 2008. "Risk-Return 
Analysis of Islamic Banks' Investment Deposits and Shareholders' Fund", Managerial Finance, Vol. 34, No. 10, 695-707

Shahinpoor, N. 2009, "The Link Between Islamic Banking and Microfinancing", International Journal of Social Economics, Vol. 36, No. 10, 996-1007

Siddiqi, Muhammad N. 2000. "Islamic Banks: Concepts, Precepts and Prospects", Review of Islamic Economics, Vol. 9, 21-36

Syafe'i Antonio, Muhammad. 2001. Bank Syariah dari Teori ke Praktik, Gema Insani Press dan Tazkia Institute

Warde, Ibrahim. 2009. Islamic Finance Keuangan Islam dalam Perekonomian Global, Penerjemah: Andriyadi Ramli, Yogyakarta: Pustaka Pelajar

Bank Indonesia. 2012. Statistik Perbankan Syariah, November, 1-63, www.bi.go.id 